\title{
The Use Of Sessional Teachers In Universities: Faculty Of The Built Environment, University Of New South Wales Australia
}

Nancy Marshall Ph.D., University of New South Wales, Australia

\begin{abstract}
This paper discusses the issues and realities presented by the casualisation of higher education teaching staff. It uses a case study from the University of New South Wales [UNSW] in Sydney Australia. The research presents and analyses perspectives from two key stakeholders in a university [students and academic management] on the use of sessional [also called casual or part-time] teachers in a professional faculty - the Built Environment. The strength of this paper lies in the presentation of the student voice and the reflections of an Associate Dean of Education who is ultimately responsible for ensuring quality learning and teaching in a faculty. Both of these are perspectives that are rarely heard in the current literature on this issue.

Although this paper uses an Australian case study, the discussion of the issues and challenges of the casualisation of higher education teaching staff has transcending value to universities and colleges around the world. Questions posed throughout the paper challenge traditional ideas of engaging part-time teachers in universities and thus, by default, set a framework for further study on this contentious practice.
\end{abstract}

Keywords: University; Teaching; Casualisation of Teaching; Higher Education; Sessional Teachers

\section{AUSTRALIAN HIGHER EDUCATION CONTEXT}

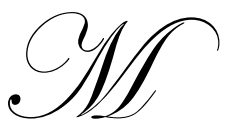

any researchers in Australia (Kift 2002, Bradley 2008, Percy and Beaumont 2008, Cowley 2010) have documented the recent and significant growth in the use of sessional staff in universities around the world. Based on practice and the literature, there is no sign that the practice or policy direction to rely on sessional teachers to significantly contribute to the learning and teaching in universities will change. In fact, it is likely that the use will increase. As such, the employment conditions and management of sessional staff is coming under increasing scrutiny in the tertiary sector in Australia. The impact that these teachers have on the student experience is also under review.

In 2008, Bradley et al released a Review of Australian Higher Education Final Report indicating that currently, 40-50\% of teaching staff at Australian universities are sessional staff. These numbers differ by university and by faculty [which have different disciplinary approaches to lecturing, tutoring, lab demonstrating, student research supervision, and studio teaching]. This reflects a relatively recent change in the higher educational context, the corporatisation of and operational environments of Australian universities. Employing staff on a sessional basis has become a standard teaching delivery model for Australian universities as it seen, by management, to enable flexibility and adaptability of staff teaching capacities and is economically effective (Gottschalk and McEachern, 2010). Whilst this model works for many of the staff, other sessional staff are underwhelmed by the management and opportunities of the system. 
Research indicates that many sessional teaching staff experience an employment cycle which includes: poor administrative processes; poor or lack of inductions, training and support; poor remuneration; reduced inclusion and recognition of contribution within faculties, and have little hope of a career path as a permanent academic (Gottschalk and McEachern 2010; University of Queensland 2003). The poor selection, management and support processes for sessional staff are specifically highlighted as having the potential to threaten the quality of the teaching and learning environment and outcomes for students (Australian Learning and Teaching Council 2008).

In 2008, the national Australian Learning and Teaching Council (ALTC) released the RED Report [Recognition, Enhancement, Development: The Contribution of Sessional Teachers to higher Education] detailing the experience of the management of sessional staff and making wide-ranging recommendations for more systemic and sustainable policy and practice; greater employment and administrative support; improved induction and academic management; greater support of career and professional development and increased reward and recognition for sessional staff within universities.

Whilst much is written about the sessional staff experience, much of the discourse unpacks the issues and opportunities in general terms and is mostly from an academic developer's perspective. Very little data actually exists at the faculty level about who sessional staff are, the volume of teaching they do and the responsibility they have - little evidence exists about the true costs and challenges part-time teachers present to the student cohort and university administration.

\section{UNIVERSITY OF NEW SOUTH WALES, FACULTY OF THE BUILT ENVIRONMENT CASE STUDY}

The case study used in this research is a professional, Built Environment [BE] Faculty at the University of New South Wales [UNSW] in Sydney Australia. Built Environment offers undergraduate degrees in Architecture, Architectural Computing, Interior Architecture, Landscape Architecture, Industrial Design, Planning, and Building/Construction and postgraduate degrees in Architecture, Planning, Building/Construction, Property and Development, Urban Development and Design, and Sustainable Development. The Faculty has 71 full-time academic staff, 10 research-only staff, 31 administrative staff, 2300 undergraduate students and 550 postgraduate (coursework) students and 120 research students.

\section{The Use Rates of Sessional Staff}

At present the Faculty relies on sessional staff to play a substantial role in the delivery of its undergraduate and postgraduate programs. Not atypical, in 2010 alone, 677 contracts were provided to 402 different sessional staff. The types of work conducted by these industry practitioners, academics from other universities, and undergraduate /postgraduate students includes: teaching and administering entire core and elective courses; conducting studio or tutorial sessions; supervising research students; giving one-off guest lectures in established courses; and marking student assessment tasks. A number of these individuals were employed in a variety of roles providing one or more type of service - each role requiring very different skills, knowledge and patterns of administrative, learning and teaching support.

Tables 1 and 2 below list the percentage of full courses convened by sessional staff, by degree program in semesters 1 and 2 in 2010. Amongst the degrees there is considerable variation ranging from $0 \%$ in a single semester for the Bachelor of Industrial Design, Master of Sustainable Development and the Master of Urban Development and Design to 66\% in one or both semesters for the Bachelor of Construction Management and for the Master of Planning. Ten out of 13 programs $(76 \%)$ had at least $25 \%$ of their courses convened by sessional staff for at least one semester, with 7 out of the $10(70 \%)$ had at least $40 \%$ of their courses taught by sessional staff for at least one semester. 
Table 1: Number and percentage of courses delivered by sessional staff by undergraduate degree

\begin{tabular}{|l|c|c|c|c|}
\hline \multirow{2}{*}{ Undergraduate Degrees } & \multicolumn{2}{|c|}{ Semester 1 } & \multicolumn{2}{c|}{ Semester 2 } \\
\cline { 2 - 5 } & No. of courses & \% of all courses & No. of courses & \% of all courses \\
\hline Architecture & 5 & 26 & 7 & 30 \\
\hline Architectural Computing & 2 & 25 & 2 & 18 \\
\hline Construction Management + Property & 12 & 66 & 10 & 66 \\
\hline Industrial Design & 0 & 0 & 2 & 16 \\
\hline Interior Architecture & 5 & 31 & 9 & 64 \\
\hline Planning & 6 & 37 & 7 & 46 \\
\hline Landscape Architecture & 3 & 21 & 5 & 41 \\
\hline Total & $\mathbf{3 3}$ & & $\mathbf{4 2}$ & \\
\hline
\end{tabular}

Table 2: Number and percentage of courses delivered by sessional staff by postgraduate degree

\begin{tabular}{|l|c|c|c|c|}
\hline \multirow{2}{*}{ Postgraduate Degrees } & \multicolumn{2}{|c|}{ Semester 1 } & \multicolumn{2}{c|}{ Semester 2 } \\
\cline { 2 - 5 } & No. of courses & \% of all courses & No. of courses & \% of all courses \\
\hline Architecture & 3 & 30 & 2 & 18 \\
\hline Construction Project Management & 1 & 25 & 3 & 60 \\
\hline Planning & 2 & 66 & 3 & 60 \\
\hline Property + Development & 2 & 50 & 2 & 66 \\
\hline Sustainable Development & 0 & 0 & 1 & 20 \\
\hline Urban Design + Development & 3 & 50 & 0 & 0 \\
\hline Total & $\mathbf{1 1}$ & & $\mathbf{1 1}$ & \\
\hline
\end{tabular}

Tables 3 and 4 below list the number and percentage of face-to-face teaching hours for sessional staff in each degree for semesters 1 and 2, 2010. Again, there is a wide variation ranging from a total average for both semesters of $45 \%$ for the Master of Construction Project Management to a total average of $81 \%$ for the Bachelor of Architecture. Per annum, across all degrees, 35,797 hours were taught of which 25,906 hours were delivered by sessional staff - this equates to $72 \%$ of all face-to-face hours.

Table 3: Number and percentage of face-to-face teaching hours done by sessional staff in undergraduate degrees

\begin{tabular}{|l|c|c|c|c|c|c|}
\hline \multirow{2}{*}{ Undergraduate Degrees } & \multicolumn{3}{|c|}{ Semester 1 } & \multicolumn{3}{c|}{ Semester 2 } \\
\cline { 2 - 7 } & $\begin{array}{c}\text { Total } \\
\text { hours }\end{array}$ & $\begin{array}{c}\text { Sessional } \\
\text { hours }\end{array}$ & $\begin{array}{c}\text { \% of all } \\
\text { hours }\end{array}$ & $\begin{array}{c}\text { Total } \\
\text { hours }\end{array}$ & $\begin{array}{c}\text { Sessional } \\
\text { hours }\end{array}$ & $\begin{array}{c}\text { \% of all } \\
\text { hours }\end{array}$ \\
\hline Architecture & 4832 & 3756 & 78 & 4221 & 3585 & 85 \\
\hline Architectural Computing & 1296 & 984 & 76 & 982 & 622 & 63 \\
\hline Construction Management +Property & 887 & 662 & 75 & 776 & 566 & 73 \\
\hline Industrial Design & 2559 & 1617 & 63 & 1781 & 1022 & 57 \\
\hline Interior Architecture & 2739 & 1999 & 73 & 2185 & 1873 & 86 \\
\hline Planning & 1069 & 677 & 63 & 1360 & 920 & 68 \\
\hline Landscape Architecture & 2064 & 1654 & 80 & 1912 & 1486 & 78 \\
\hline
\end{tabular}

Table 4: Number and percentage of face-to-face teaching hours done by sessional staff in postgraduate degrees

\begin{tabular}{|l|c|c|c|c|c|c|}
\hline \multirow{2}{*}{ Postgraduate Degrees } & \multicolumn{3}{|c|}{ Semester 1 } & \multicolumn{3}{c|}{ Semester 2 } \\
\cline { 2 - 7 } & $\begin{array}{c}\text { Total } \\
\text { hours }\end{array}$ & $\begin{array}{c}\text { Sessional } \\
\text { hours }\end{array}$ & $\begin{array}{c}\text { \% of all } \\
\text { hours }\end{array}$ & $\begin{array}{c}\text { Total } \\
\text { hours }\end{array}$ & $\begin{array}{c}\text { Sessional } \\
\text { hours }\end{array}$ & $\begin{array}{c}\text { \% of all } \\
\text { hours }\end{array}$ \\
\hline Architecture & 2237 & 1318 & 59 & 2147 & 1347 & 63 \\
\hline Construction Project Management & 203 & 95 & 47 & 180 & 84 & 47 \\
\hline Planning & 150 & 93 & 62 & 217 & 166 & 76 \\
\hline Property + Development & 180 & 129 & 72 & 147 & 99 & 67 \\
\hline Sustainable Development & 220 & 115 & 52 & 315 & 143 & 45 \\
\hline Urban Design + Development & 709 & 555 & 78 & 429 & 339 & 79 \\
\hline
\end{tabular}


The data in Tables 1-4 indicate that a substantial amount of the teaching is being managed and taught by sessional staff in the Built Environment. This indicates that a substantial amount of program quality, consistency and control rests with sessional staff. It also indicates that a large percentage of the teaching and learning outcomes for students and the student experience are in the hands of sessional staff.

\section{Students' Perspectives on the Use of Sessional Staff}

The student voice in a university should not be underestimated. As part of an initiative to document and improve the overall student 'lived experience' in the Faculty of the Built Environment, 13 focus groups were conducted with students from all degree programs. Students self-selected (from a general invitation to participate) and represented first through to fifth year undergraduate students and all years of postgraduate students. Standard qualitative protocols were used to organise, document and report on the findings of the focus groups. For this paper, the results of those focus groups have been de-identified and aggregated and focus on the students' views about teaching and sessional teachers. Overall, 104 students were involved in 13 different focus groups - their quotes, in italics, are peppered throughout this paper.

The students held mixed opinions towards sessional staff seeing both positive and negative aspects of having part-time teachers delivering substantial parts of their degree. The types of comments made were seen across the degrees, i.e. regardless of whether a student was in Landscape Architecture or Industrial Design or Planning, there were no comments or reflections that were unique to one student group. Similar reflections and comments were received from all groups.

In summary, the students actually noticed how hard full-time teachers work and could appreciate why sessional staff are used in the first instance. "The full-time teachers seem to have a pretty heavy work load" (Industrial Design Student). The students did not mind if $72 \%$ of the Faculty's teaching was done by part-time staff, as long as they were good teachers. "Good teaching is a natural ability; it's not really about whether the teacher is part-time or full-time" (Planning Student). However, many students thought that part-time teachers could just be used for specialised areas or just hired for specific projects, rather than general teaching.

Students generally agreed that part-time teachers have their strengths and weaknesses - their comments mostly addressed the cross-cutting themes of: university administration and procedures, teaching ability; time and availability; industry knowledge and connections; students who are hired as tutors; and the rapport that students expect to have with their teachers. Each of these themes is discussed below from the students' perspectives.

\section{University Administration and Procedures}

According to the students, sessionals tend to have less knowledge of the university system and are not helpful to the students with administrative matters. Further, students felt that sometimes part-time staff do not quite know their role and how they or their course fit within the overall degree program.

On a positive note, there was acknowledgement that part-time staff "aren't fully institutionalised" and "don't take feedback about the course personally" which were seen as good aspects to bring to a degree program (Interior Architecture Student). As such, students believed they could critique their learning experience and the university to these staff who seem to be less tied to the university, with more honesty and without the feeling of retribution through low grades.

Several students also noted that sessional teachers were typically more understanding of student pressures and appreciate that students also have responsibilities outside of the University. On the opposite side of the debate, other students believed that part-time staff do not always understand the pressures of being a student and can be "unreasonable in their expectations with assignments and due dates" (Architecture Student). 


\section{Teaching Ability}

All focus groups talked at length about the ability of sessional staff to teach effectively and efficiently. Generally, students believed that all "staff are good and there is a good range of teachers" (Industrial Design student). On a positive note, part-time teachers were seen to bring a variety of fresh opinions, in-depth knowledge of their subjects, and different teaching styles into the classroom and studio. On the other hand, they were criticised for their inability to teach well, some for being inaccessible and others for being somewhat uninspiring. Many participants believed that the communication skills of part-time staff were not as good as full-time staff as they do not "teach for a living". "In the beginning they [sessional staff] are learning like we are and their communication skills aren't as adept as the [full-time] lecturers. It takes them usually a month or so to build up communication and trust with students. Often by the end of it, they are as fabulous as lecturers if not more so because their work experience is present" (Industrial Design Student).

All student groups wished there would be more communication between the full-time and the part-time teachers. This problem seemed to be highlighted when the sessional staff member was a tutor (in a class being run by a full-time teacher who may not have briefed the tutor appropriately or in detail). The sessional staff member might have been a good teacher, but was not informed sufficiently about the project itself.

Some students believed that part-time staff were not properly trained nor did they have any teaching experience or skills to be effective. Students questioned the process by which they are selected and trained. They also mentioned that even though some part-time teachers were repeatedly identified as poor teachers they have never been replaced. One (Planning) student said "I get the impression the Faculty is desperate" with some of the staff they hire and the choice is not always the best option.

"Even though their work may be brilliant, they are not teachers at the end of the day" (Interior Architecture Student). Part-time staff were seen to bring in new ideas and new perspectives and provide different, but often more critical, analytical feedback compared to the full-time staff. "Sessional staff need to learn about giving feedback and be given some assessment techniques especially - a comment such as 'are you serious?' is not helpful critique" (Interior Architecture Student). Part-time staff were seen to be less judgemental towards students as these teachers had no prior knowledge of a student's academic history - students did not feel prejudged by sessional staff. Students noticed more disparity in the amount of feedback that was offered to some students and not others from sessional staff: "one tutor offers students 20 minutes and another 1 hour" (Interior Architecture Student).

It was felt that (unlike some full-time staff who have been teaching a long time) part-time staff were enthusiastic, committed to teaching (not research) and passionate about the profession and their subject material, as they were not repeating "the same courses day-in-day-out" (Planning Student). Alternatively, some sessional staff were not seen to be as engaged at all with teaching when compared to full-time staff. Some tutors were negatively described as "too busy," "too quiet," "pushing their own agenda" or "were there just so they can put it on their resume." (Architecture, and Interior Architecture Students).

\section{Availability}

The biggest and most consistent criticism of part-time staff was that, because they did not have an office at the university, they were difficult to contact in person (outside of class hours). A part-time teacher's unwillingness to stay behind after class gave the impression to students that they are more committed to their own professional practice than they are to the students and their teaching. "Practitioners need to be able to give their time to students" (Construction Student). "They come in once a week, get paid well, and don't care about the well-being of the student" (Planning Student). Many students felt that sessional staff were easily accessible by email or over the phone and were generally responsive to student needs through these modalities. 


\section{Industry Knowledge and Industry Connections}

Students extensively acknowledged that part-time staff have current, up-to-date workplace experience with in-depth knowledge of current trends and technologies, all of which were seen as being important in such the evolving industry. One student noted that "industry experience is "the most important thing a teacher can give to a student" (Construction Student). Sessional staff give practical and interesting examples which illustrate a point and demonstrate how theory could be applied to practice. Relevant and practical examples from the practitioner's work "bring life to the lectures" (Planning Student). There was agreement among the students that part-time staff were effective teachers who had "connections to the real world" and were able to relate classes to what is "happening now, not in the past" (Landscape Architecture Student). It was also felt that part-time staff had connections to the industry which could assist students in gaining work experience placements. Students felt they benefitted from the exposure to and experience in proposing ideas/work to potential clients. Most students appreciated that sessional staff were likely hired because they were good in industry or simply because they had real industry experience: "you are getting criticism or being guided by the very people you will be working for in the near future" (Interior Architecture Student).

Part-time teachers have current experience and valuable insight into many different parts of industry and were seen to be very engaged with their own practice. Students enjoyed seeing the work of the part-time staff and learned from watching them work. Students often suggested that part-time teachers' knowledge base is as good as, if not better, than that of full-time staff. Comparatively, permanent academics were seen to deliver more outdated course material and had old-fashioned perspectives. "The younger part-time staff can be brilliant at computer programs an up on new technologies" (Industrial Design Student).

Many students admitted that they appreciated a mix of full- and part-time staff teaching together which they believed gave them 'the best of both worlds': an academic perspective and someone who oversaw administrative problems efficiently within the university and new ideas from industry presented by a practitioner.

\section{Students as Tutors}

Some students suggested that it was inappropriate to have other undergraduate students as tutors - "we're not keen on students teaching students; one day they were instructing us in class and the next day they are sitting an exam in another class with us" (Interior Architecture Student). Others appreciated the peer learning experience when it was managed well. It was suggested that when students are used as tutors, they should be given more support from and the chance to go over material in-depth with the lecturer. One experience was described as "you're tutoring, here's your class" and the student tutor was left to their own devices (Planning Student). For those who had been senior-student tutors, their experiences could have been more rewarding.

\section{Rapport with Teachers}

Often, because of the size of the student body in built environment disciplines and the small studio teaching setting, students get to know their full-time lecturers and vice versa and could approach them directly for help or with administrative questions. Most staff are recognised for their relevant knowledge and being friendly with the students outside of class. Participants agreed that there was less of an opportunity to develop these relationships with part-time staff as compared to the permanent staff and wished there was more of a chance to do so. Students want to establish a rapport with their teachers - these connections often lasts long after their tenure at university when the two become professional colleagues.

\section{An Associate Dean's Perspective on the Use of Sessional Staff}

This research incorporates personal narrative in the form of autoethnography which adds a rich, personal layer to the research, by placing the author at the centre of it. Reed-Danahay $(1997,9)$ states that autoethnography "is a form of self-narrative that places the self within a social context. It is both a method and a text. It can also be done by an autobiographer who places the story of his or her life within the story of the social context in which it occurs." The paper is reflective, but also, as per Etherington (2004), reflexive; that is, as the researcher, I 
acknowledge my own experiences in the context of what is being studied. Patton $(2002,88)$ believes that "autoethnography increases the importance of voice and raises the stakes because an authentic voice enhances the authenticity of the work."

My role as the Associate Dean of Education is to ensure quality learning and teaching is occurring for all staff and students in the Faculty. Based on the context, the student perspective and other quality assure and financial evidence, the use of sessional staff is an area which is in need of greater oversight, management and attention. The Faculty performance review and management processes that surround all staff, but especially the part-time staff, are in need of revision. With such high percentages of teaching done by part-time staff, and with no overarching system of sessional staff selection, management and quality assurance, the BE is in a very vulnerable position - a situation that is not unique to this Faculty.

Professional faculties are known to extensively use sessional staff teachers given the very practical nature of their disciplines and professions. Given Australia's higher education context and the Faculty's specific circumstances, major challenges exist with respect to the learning and teaching occurring in the Faculty. Given the context and issues drawn from the students' comments, challenges related to philosophy and pedagogy; quality assurance; management and logistics; and economic realities are problematized below. There are many questions posed in this final section of the paper - these require further study and consideration if the challenges of the teaching environment presented are to be addressed.

\section{Challenge 1: Philosophy and Pedagogy}

Although university and faculty mission statements and strategic plans exist, rarely is a philosophy of learning and teaching or the pedagogy of a discipline explicitly pronounced or articulated. Permanent academics might argue these are tacit knowledge, but for part-time staff, these are necessities that could greatly assist with their integration into the overall community of practice. How a sessional staff fits within a faculty and a degree program with a particular set of core values is critical to their understanding of their roles within these administrative and substantive structures. These core values help define 'the built environment' and add an intellectual richness to the collective curricula within the Faculty. They also frame what educational approach is expected to best prepare our students for the world ahead. These concepts represent not only the Faculty's educational core values but also the Faculty's values across education in general, research and management.

The challenge above begs certain questions...Would or how would a faculty-wide, philosophy and approach to teaching help reassess and recondition the relationship between the Faculty and its sessional staff? What professional conditions are 'sacred cows' when it comes to learning and teaching in the built environment disciplines? Should sessional staff be involved in articulating a set of core values and philosophy for an academic faculty? What are the 'costs' to the students, vis-à-vis teaching quality, staff availability, or theoretical knowledge capacities, that are not evidenced in the existing studies on sessional staff? Are students and staff expectations of the classroom experience aligned with each other? Do professional faculties 'over-teach', that is, are there efficiencies that the Faculty can glean with a review of its overall teaching practices?

\section{Challenge 2: Quality Assurance}

A key tenet of my job as the Associate Dean of Education is to ensure the quality of the Faculty's learning and teaching. An overall philosophy is needed to ensure clear expectations and deliverables are understood by all teaching staff, including the part-time staff. The Built Environment is a professional faculty and has a long tradition of relying on industry practitioners to teach and assist with the acculturation of students into the profession. Besides this history, the basic teaching method of the design-based disciplines such as architecture is that of the design studio which naturally has a low student:teacher ratio. These two practices create tensions around who should teach in a professional faculty and whether or not there are other modes of teaching that are more efficient than the personal studio teaching mode.

My job is to ensure effective, relevant, challenging and engaging learning is taking place amongst the student body. Scale becomes an issue: with some 70 permanent and 400 sessional staff delivering curricula in 13 
different degree programs for a total of $\sim 35,800$ hours of teaching in one year (of which $\sim 25,900$ is done by casual staff), quality assurance becomes a huge issue. Content, delivery modes, parity, consistency, knowledge transference and student satisfaction across so many different students cohorts is very difficult to manage, especially when trying to ensure a high quality product.

Many questions can be asked... what are the actual attributes of value that sessional staff bring to the classroom? To what extent if any, are students disadvantaged because a sessional staff member is teaching the curriculum? What is an appropriate percentage of sessional teaching that can be done in a professional faculty whereby the quality and consistency is maintained? What proportion of full courses should or could be convened by sessional staff? Should sessional act only in support of permanent academic staff? Are there legitimate disciplinary differences in acceptable sessional teaching levels i.e., is a high rate of sessional staff justifiable in the design-based disciplines where a teacher:student ratio in the studio is 1:15? Should more or fewer casual staff be used in undergraduate versus postgraduate studies? How much marking can be reasonably outsourced to casual staff? Are there some types of teaching which should never be delivered by sessional staff? How can the theoretical content of material be ensured if taught mostly by practitioners? Should sessional staff only be used to teach specific course content (as the students suggested)? Should undergraduate students ever act as teachers or tutors in their own faculty?

\section{Challenge 3: Management and Logistics}

As mentioned at the start of this paper, the casualisation of teaching staff is endemic within the Australian higher education system and this trend shows no signs of reversing. Despite there being a whole of university [UNSW] approach to part-time teachers through the adoption of a Sessional Teaching Staff Strategic Action Plan in 2006 (Scoufis and Mason, 2008), in reality faculties are left to their own management and support systems to deliver effective and efficient teaching.

In 2008, the RED Report, identified five major domains for improving the quality of sessional staff management and teaching. These included: systemic and sustainable policy and practice; employment and administrative support; induction and academic management; career and professional development; and reward and recognition. Many of these systems do not clearly exist for permanent academics, let alone existing in a parallel process for sessional staff. It is an enormous task to streamline the management of this potentially 400 different parttime academics each year. Sessional staff do not figure neatly in unionised employment; as individuals, they represent a range of qualifications from student to highly acclaimed professionals; and a collective, they provide a a range of services from casual marking to supervising $\mathrm{PhD}$ students. From a management perspective, in order for these staff to be successful, a range of administrative and learning and teaching scaffolding is needed in an already overstretched academic setting.

Again, the management situation begs several questions...should the Faculty invest in all of its sessional staff? If not, where is most support needed and what form should it take? Should staff be paid based on their experience and qualifications or for the job being done or both? How can the mechanics of teaching be taught efficiently? Which, if any, issues could be solved if part-time staff were given a permanent or permanent fractional appointment? How can parity be ensured by many sessional teachers across time and student cohorts? At what cost can the complaints in the RED Report be ameliorated by any faculty?

\section{Challenge 4: Economic Realities}

Behind all of these issues, challenges and opportunities is the economic reality of the situation - sessional staff are much cheaper than employing more full-time academics. The truth is that the university system is being corporatised. Its workforce is being casualised. Sessional staff fill a need in a market-driven venture. Academic management has changed substantially in the last 15 years - no longer can the system afford to offer its 'clients' (i.e. the students) an valuable 'product' (i.e. an education) with extensive permanent staff, huge facilities/campuses and high overhead costs. All universities are looking to reduce operating costs. Accurate course costing formulas are very complex and not very well understood by most academics. The example below attempts to very crudely depict the different costs when a course is delivered by a permanent versus sessional teacher. This does not consider any overheads or revenue and hence does not depict the net cost (+ or -) of delivering a course. 
In the $\mathrm{BE}$, a mid-career, permanent academic cost the university approximately $\$ 135,000$ (which includes on-costs). That person is expected to convene and deliver roughly four courses which is considered to be $\sim 40 \%$ of a full-time workload (equating to $\$ 54,000$ ). An academic is also expected to be 'research active' which represents $\sim 40 \%$ of a workload and must contribute $\sim 20 \%$ of their time to 'service'. Crudely broken down, a lecture-only course (not considering tutorials) delivered by a full-time academic costs approximately $\$ 13,500$ in wages. When a sessional staff runs that same course, they are paid on average $\$ 8,000$. If a savings of $\$ 5,500$ is made per course is then multiplied by the 97 courses run by sessional staff per annum, a savings of $\$ 533,500$ is created each year for the BE. The savings would be even greater when a financial analysis is calculated on face-to-face teaching hours. If, on average, a mid-career, permanent academic spends $40 \%$ of his or her time on teaching and works 1680 hours/year, then each academic teaches $\sim 672$ hours. In order to cover the 25,900 hours delivered by sessionals, the BE would need to hire an additional 38.5 staff (at an average rate of $\$ 135,000 /$ year) costing the Faculty an additional $\$ 5.2$ million per annum. For the same hours currently being taught by sessional staff the cost to the Faculty is $\$ 3.2$ million. In sum and very crudely, the casualisation of teaching saves the Faculty $\$ 2$ million/year. For a relatively small Faculty (80 academic staff and 3000 students), this is substantial.

There is no doubt that, financially, it is cheaper to have sessional staff teaching the BE curricula. However, several questions could be asked...how cost effective would it be to have all teaching done by sessional staff? Are sessional staff really efficient teachers? Are the current pay rates $(\$ 123 /$ hour average) fair and respectful? Are the savings made by using sessional staff reinvested into the teaching and learning of the Faculty, and should they be? How could a cost/benefit analysis be done on teacher training cost compared to the quality benefits gained from such training. If the BE hired more permanent academics to cover more of the teaching, would it equally increase its research revenue?

\section{CONCLUSION}

Do Australian universities rely too heavily on and expect too much from a casual workforce? Does this place them and their students in a precarious position? Whilst students clearly value and appreciate the input and contribution of sessional staff, acknowledging areas in need of improvement the enormous dependency on this fluctuating community leaves a substantial component of student learning and outcomes to chance. This potentially threatens a university's professional reputation and success. Great oversight, recognition of the situation and management of sessional staff experiences is needed to ensure cost efficiency does not compromise educational quality.

\section{AUTHOR INFORMATION}

Nancy Marshall Ph.D. is currently the Associate Dean of the Faculty of the Built Environment at the University of New South Wales, Sydney Australia. As a member of the Senior Executive Management Team in the faculty, Nancy leads, supports and facilitates major organisational and educational change for 80 permanent academic staff, 400 part-time teaching staff and 3000 undergraduate and postgraduate students. She is responsible for Faculty-wide strategic directions and the implementation of learning and teaching initiatives that have an impact on the Built Environment's academic program performance and student experience. Nancy also teaches in the Faculty's Urban Planning Program. E-mail: n.marshall@unsw.edu.au

\section{REFERENCES}

1. Australian Learning and Teaching Council. (2008). The RED Report. Canberra, AUS: Australian Government Department of Education, Employment and Workplace Relations.

2. Bradley, D., Noonan, P., Nugent, H. \& Scales, B. (2008). Review of Australian Higher Education Final Report. Canberra, AUS: Australian Government Department of Education, Employment and Workplace Relations.

3. Bryson, C. \& Blackwell, R. (2006). Managing Temporary Workers in Higher Education: Still at the Margin? Personal Review, 35(2) 207-224. 
4. Cowley, J. (2010a). Being Casual About Our Teachers: Understanding More About Sessional Teachers in Law. University of New South Wales Faculty of Law Research Series 2010. Working Paper 48. Retrieved from: http://law.bepress.com/unswwps/flrps10/art48.

5. Cowley, J. (2010b). Confronting the Reality of Casualisation in Australia: Recognising Difference and Embracing Sessional Staff in Law Schools. QUT Law and Justice Journal, 10(1) 27-43.

6. Etherington, K. (2004). Becoming a reflexive researcher. London, UK: Jessica Kingsley Publications.

7. Gottschalk, L. \& McEachern, S. (2010). The Frustrated Career: Casual Employment in Higher Education. Australian Universities Review, 52(1) 37-50.

8. Kift, S. (2002). Assuring Quality in the Casualisation of Teaching, Learning and Assessment: Towards Best Practice for the First Year Experience. The 6th Pacific Rim First Year in Higher Education Conference 2002: Changing Agendas - Te Ao Hurihuri, University of Canterbury, Christchurch, New Zealand, 8-10 July, 2002.

9. Nicolettou, A. \& Flint, S. (2004). Holistic Approach to Professional Development and Support for Sessional Teaching Staff. Higher Education Research and Development Society of Australasia. Retrieved from: http://www.herdsa.org.au/conference2004/Contributions/NRPapers/A057-jt.pdf.

10. Patton, M. Q. (2002). Qualitative research and evaluation methods $\left(3^{\text {rd }}\right.$ ed). Thousand Oaks, USA: Sage Publications.

11. Reed-Danahay, D. E. (Eds). (1997). Auto-ethnography: rewriting the self and the social. Oxford, UK: Berg Publications.

12. Scoufis, M. \& Mason, C. (2008). Whole of University Approach - Policy and Practice. The RED Resource. Canberra, AUS: Australian Government Department of Education, Employment and Workplace Relations. 